\title{
Effect of Different Irrigation Treatments on Growth and Development of Schefflera arboricola, (Hayata) Kanehira
}

\author{
Samia Z. El-Bably and Ola A. Amin \\ Ornamental Plants and Landscape Gardening Research \\ Department, Horticulture Research Institute, Agriculture \\ Research Centre, Cairo, Egypt.
}

\begin{abstract}
7 HIS study was carried out at the Ornamental Plant Research Department, Horticulture Research Institute, Agriculture Research Centre, Giza, Egypt in March of two seasons, 2011-2012 and 2012-2013. Three locations i.e. the nursery, the black saran house and the office and 4 amounts of water $(300,450,600$ and 750 $\mathrm{cm}^{3} /$ pot/week) for irrigating, Schefflera arboricola, plants were compared. The following results were obtained:

Plants grown in the nursery ranked the first among other treatments for the following characters; plant height, root length, root fresh and dry weights, leaf and stem contents of total carbohydrates, leaf contents of total chlorophyll and carotenoids. Plants grown in the saran house resulted in high values of plant height, number of branches, number of leaves, shoot fresh and dry weights. On the other hand, plants kept in the office for ornamentation scored the lowest values of all studied characteristics.
\end{abstract}

Plants received $300 \mathrm{~cm}^{3} /$ pot/week for irrigation achieved the highest rank concerning root length. Irrigating plants with 450 $\mathrm{cm}^{3} /$ pot/week resulted in the highest values concerning plant height, number of branches, number of leaves, shoot fresh and dry weights, root length, content of total carbohydrates in leaves and stem. Irrigation with $600 \mathrm{~cm}^{3} /$ pot/week gained the highest category for characters of plant height, shoot fresh and dry weights, root length, root dry weight and leaf content of total carbohydrates. Plants that obtained the lowest values in all characteristics were committed with those irrigated with $750 \mathrm{~cm}^{3} /$ pot/week.

The best watering amounts to be used in each location in order to attain the best ornamental characters, could be deduced from the interaction of the two previous factors as follows: The highest values of plant height, number of branches, number of leaves, shoot fresh and dry weights were achieved when 600,450 or $300 \mathrm{~cm}^{3} /$ pot/week were used to irrigate plants in the nursery, the saran house and the office, respectively. On the other side, using $750 \mathrm{~cm}^{3} / \mathrm{pot} /$ week for watering resulted in the lowest values of number of branches, number of leaves, shoot fresh and dry weights for plants in the three locations, in addition to plant height for plants grown in the saran house or kept in the office.

It is recommended to grow Schefflera arboricola plants in the nursery rather than the saran house for production purposes, and to use 
600,450 or $300 \mathrm{~cm}^{3} /$ pot/week to irrigate plants in the nursery, the saran house and the office, respectively. This will save better amounts of water for other purposes.

Keywords: Schefflera arboricola, Watering amount, Nursery, Saran house, Office.

Schefflera arboricola (Hayata) Kanehira, (syn. Heptapleurum arboricolum, H. sasakii) dwarf schefflera, parasol plant, umbrella tree, dwarf umbrella tree, Hawaiian umbrella tree, Arboricola tree, Hawaiian Elf, is a plant in the Araliaceae family, native to the islands of Taiwan and Hainan, China. It is an evergreen shrub reach to 3-4 m tall. The trailing stems are weak and frequently scramble over other vegetation. The leaves are palmate compound, and have 7-9 leaflets. Leaflets are $9-20 \mathrm{~cm}$ long and $4-10 \mathrm{~cm}$ across in the wild, but normally smaller when cultivated. Flowers are produced in a $20 \mathrm{~cm}$ panicle of small umbels, each umbel 7-10 mm diameter with 5-10 flowers. It is a tender frost tolerant, belongs to the climatic zone USDA: 10-11. It needs a light shade, humid air and a regular watering. Soil should be moist but not wet. Never should be sit in water, or the roots will rot. It is a common houseplant, popular for its ability to tolerate neglect and poor growing conditions. Many cultivars exist with a variety of leaf colors and patterns, with variegation ranging from creamy-white to yellow edges or centers, and dwarf forms especially selected for. It can be useful as a bonsai as well and is popular as an indoor bonsai.

Under the right conditions, this plant will produce aerial roots that, when they reach the ground, will convert to fully functional roots. They give the plant an unusual and interesting appearance. Three conditions must be maintained for the plant to produce them: a high growth rate, insufficient trunk roots (the plant is root bound or these roots are pruned) and constant, very high humidity. (Everett, 1981, Faucon, 2005, Kojian 2009, Starr \& Starr 2009, Wikipedia (2009) and Zhenzhe \& Changze, 2009).

Quantifying water requirements of each crop is very necessary to increase the water use efficiency in the Egypt's agricultural production. However, there is a lack of available information in this concern especially in the field of ornamental plants. With the forthcoming of the reduction in Egypt Nile River quota, we are obliged to modulate irrigation methods to decrease water lose.

Numerous of authors had discussed the problem of diminishing water resources and its impact on agriculture. Valdez-Aguilar et al. (2009) stated that scarcity of water for landscape irrigation is a major concern in arid and semiarid regions as a result of the competition with the urban population. Competing claims from urban, agricultural, environmental, and industrial groups leaves less water for use in landscape maintenance. Lucia (2009) remarked that knowledge of plant performance under reduced irrigation has the potential to reduce drastically the amounts of the applied container irrigation water, but there is still

Egypt. J. Hort. Vol. 41, No.1 (2014) 
a lack of information about growth and physiological behavior relative to potted ornamentals grown under limited water availability. Iersel et al. (2010) reported that more efficient irrigation practices are needed in ornamental plant production to reduce the amount of water used for production as well as fertilizers runoff. Salvador et al. (2011) stated that irrigation water use in private landscapes represents an increasing share of total water use in semiarid areas. When the net landscape irrigation requirements were estimated according to reference evapotranspiration. It is noticed that over-irrigation was common in $60 \%$ of the households. Only $34 \%$ of the households showed adequate irrigation, while $6 \%$ of the households under-irrigated their landscape areas. Álvarez et al. (2013) declared that the irrigation water requirements and sensitivity to water deficits of ornamental plants is of great interest to horticultural producers for planning irrigation strategies.

Response to irrigation amounts and to water stress differs from one plant to another as mentioned by Parnell (1989). He determined the quantity of water required to supplement normal rainfall and still produce optimum growth in ornamental plants using six different irrigation rates (12.7 to $63.5 \mathrm{liter} / \mathrm{m}^{2} /$ week). He found that Cupressus sempvirens, Asparagus densiflorus, Podocarpus macrophyllus, Strelitzia reginae, Juniper proeumbens, Philodendron williamsii, Codiaeum variegatum, Brassaia actinophylla, Ilex vomitoria 'Schellings', and Cirus sinensis showed no significant growth response to different irrigation rates. Carissa grandiflora, Chrysanthemum morifolium, Ligustrum japonieum and Dracaena deremensis showed marginally significant responses. Pittosporum tobira, Hibiscus rosa-sinensis, Rhododendron sp. and Nephrolepis exaltata showed highly significant responses. Application rates between 25.4 and 38.1 liter $/ \mathrm{m}^{2} /$ week produced optimum growth responses. Application rates in excess of $38.1 \mathrm{liter} / \mathrm{m}^{2} /$ week failed to produce significant growth increases and wasted water resource.

Determining the right amount of irrigation needed to a certain crop, in relation to field capacity or evapotranspiration (ET), might be in favor of this plant and represent a good approach to save water. Irmak and Rathje (2008) stated that over-irrigation results in the following: (1) disturbs the oxygen balance in the root zone, drowns roots, reduces plant water uptake, and thus stresses plants. (2) Cause reductions in root growth (especially in the upper soil layers) and less transport of water and nutrients through the roots to the upper parts of the plant. (3) Increase harmful microbial growth and the potential for root diseases which can cause the formation of sulfides and butyric acid that are toxic to plants. (4) Cause a decrease in soil temperature, thus reducing root growth, which creates a shallow root structure. (5) Leach nutrients and pesticides from the root zone to groundwater. (6) Negatively impacts yield and wastes water and energy resources. Warsaw et al. (2009) irrigated container-grown woody ornamentals, Deutzia gracilis 'Duncan', Kerria japonica 'Albiflora', Thuja plicata 'Atrovirens', and Viburnum dentatum 'Ralph Senior', grown in 10.2 liter containers, according to a percentage of daily water use (DWU) or a traditional 
irrigation rate. Total irrigation applied was 33, 41 and $44 \%$ less than the total water applied by the control treatment of 123 liter per container. They found that plants grown under the three DWU treatments had a final growth index greater than or equal to plants irrigated by the control treatment. Irrigating according to the DWU treatments used reduced irrigation volumes, $\mathrm{NO}_{3}-\mathrm{N}$ and $\mathrm{PO}_{3}-\mathrm{P}$ losses compared with a control, while producing the same size or larger plants.

On the other hand, giving plants less water than their needs might harm growth and development and hamper their production. Correa-Tedesco et al. (2010) assessed the responses of olive (Olea europaea) growth and several physiological parameters to different irrigation levels. They found that vegetative growth was proportional to the amount of irrigation. Caser et al. (2012) subjected rooted cuttings of Salvia dolomitica, S. sinaloensis and Helichrysum petiolare to five irrigation treatments (20-100\% of container water capacity). They mentioned that growth index decreased as water stress was intensified. The lowest growth variation was observed in plants subjected at $20 \%$ of container water capacity.

Therefore, the present experiment was performed aiming to find out the response of Schefflera arboricola to different irrigation regimes in different locations.

\section{Materials and Methods}

This study was carried out at the nursery of the Ornamental Plant Research Department, Horticulture Research Institute, Giza, Egypt in March of the two seasons, 2011-2012 and 2012-2013. The second season was an exact repetition of the first one.

Transplants of Schefflera arboricola, $10 \mathrm{~cm}$ long in $12 \mathrm{~cm}$ pots, were obtained in December 2010. Plants were watered regularly and sprayed with white Kristalon solution at $3 \mathrm{~cm}^{3} /$ liter every month all over the plant life. Three months later, i.e. March 2011, plants were repotted into $25 \mathrm{~cm}$ pots filled with about $2 \mathrm{~kg}$ of a mixture of sand and silt at 1:2(v:v) and were ready for the intended treatments. The water capacity of the potting mixture was determined as follow: three $25 \mathrm{~cm}$ pots filled with the potting mixture were watered thoroughly to saturation and weighed. Pots were covered with aluminum foil to prevent evaporation before they were left in a cool shaded place to drain freely for one day. They were weighed again to calculate weight of water held by the potting mixture. Mean of the three pots representing the field capacity was found to be $750 \mathrm{~g}$, equivalent to $750 \mathrm{~cm}^{3}$ of water/pot.

A completely randomized block design in a factorial experiment was carried out, in which plants were divided into 3 groups which were put in 3 different locations, under tree shade in the nursery, the black saran house or kept in the office as indoor decoration. Pots in each location were subdivided into 4 subgroups, where they were subjected to 4 irrigation regimes, i.e. 300, 450, 600 and $750 \mathrm{~cm}^{3}$ of water/pot/week. These allocations were true for spring (March, April

Egypt. J. Hort. Vol. 41, No.1 (2014) 
and May) and autumn (September, October and November). In winter (December, January and February), one third of these amounts was deducted, to be given back in Summer (June, July and August) to the same treatments in mid week to make for the high summer temperature. Each watering treatment in each location contained 3 replicates, with 6 pots in each replicate. One year later, i.e. March 2012 data of plant height $(\mathrm{cm})$, number of branches, number of leaves, shoot fresh and dry weights $(\mathrm{g})$, root length $(\mathrm{mm})$, root fresh and dry weights $(\mathrm{g})$, were recorded. In the second season, plants were purchased from the same vendor in December 2011. All the abovementioned procedures were repeated where repotting took place in March 2012 and the same readings were recorded in March 2013.

Data were statistically analyzed using analysis of variance as described by Snedecor and Cochran (1989) and means were compared by Duncan critical range at 5\% (Duncan, 1955) by means of SAS 1995 computer program.

Samples from the three replicates of each treatment were mixed together and chemical analysis of total carbohydrate content $(\mathrm{mg} / \mathrm{d} . \mathrm{wt}$.) of both leaves and stems were carried out according to Herbert et al. (1971). Leaf content of both total chlorophyll and carotenoids (mg/f.wt.) were carried out according to Saric et al. (1976), in the Central Lab of the Horticulture Research Institute.

Meteorological data of temperature and relative humidity in addition to light intensity (using LX-101 Lux Meter) were recorded 4 times each year on the $15^{\text {th }}$ of January, April, July and October at 12:00 pm, under the three tested locations, as shown in Table (a).

TABLE (a). Temperature, humidity and light intensity measured at three locations in the Horticulture Research Institute.

\begin{tabular}{|c|l|c|c|c|c|c|c|c|c|c|}
\hline \multirow{2}{*}{ Month } & Location & \multicolumn{3}{|c|}{2011} & \multicolumn{3}{c|}{$\mathbf{2 0 1 2}$} & \multicolumn{3}{c|}{$\mathbf{2 0 1 3}$} \\
& & $\begin{array}{c}\text { Temp. } \\
\left({ }^{\circ} \mathbf{C}\right)\end{array}$ & $\begin{array}{c}\text { Hum. } \\
(\%)\end{array}$ & $\begin{array}{c}\text { Light } \\
(\text { Lux })\end{array}$ & $\begin{array}{c}\text { Temp. } \\
\left({ }^{\circ} \mathbf{C}\right)\end{array}$ & $\begin{array}{c}\text { Hum. } \\
(\%)\end{array}$ & $\begin{array}{c}\text { Light } \\
(\text { Lux })\end{array}$ & $\begin{array}{c}\text { Temp. } \\
\left({ }^{\circ} \mathbf{C}\right)\end{array}$ & $\begin{array}{c}\text { Hum. } \\
(\%)\end{array}$ & $\begin{array}{c}\text { Light } \\
(\text { Lux })\end{array}$ \\
\hline & Nursery & 21.0 & 79.0 & 6010 & 20.7 & 78.5 & 5950 & 20.7 & 77.5 & 6000 \\
\hline Jan & G.house & 23.0 & 84.0 & 5890 & 22.5 & 81.0 & 5750 & 23.0 & 80.5 & 5800 \\
\hline & Office & 22.0 & 75.0 & 395 & 21.0 & 77.5 & 390 & 21.5 & 74.0 & 385 \\
\hline & Nursery & 26.3 & 74.5 & 8380 & 26.7 & 76.0 & 8350 & 26.3 & 74.0 & 8370 \\
\hline April & G.house & 28.8 & 78.0 & 8145 & 28.2 & 77.5 & 8120 & 29.0 & 76.5 & 8140 \\
\hline & Office & 27.8 & 72.0 & 395 & 27.8 & 73.5 & 400 & 27.0 & 62.0 & 390 \\
\hline & Nursery & 34.7 & 79.0 & 9100 & 34.7 & 78.5 & 9100 & 34.7 & 79.5 & 9000 \\
\hline July & G.house & 36.0 & 84.0 & 8300 & 37.0 & 86.0 & 8400 & 35.2 & 86.0 & 8400 \\
\hline & Office & 35.5 & 78.0 & 410 & 35.3 & 70.0 & 405 & 34.5 & 72.0 & 415 \\
\hline & Nursery & 31.0 & 80.0 & 5700 & 31.3 & 81.5 & 5750 & 31.0 & 81.5 & 5800 \\
\hline Oct. & G.house & 33.0 & 83.0 & 5300 & 32.8 & 85.0 & 5100 & 33.3 & 88.0 & 5200 \\
\hline & Office & 32.5 & 76.0 & 385 & 32.2 & 78.0 & 380 & 32.4 & 81.0 & 385 \\
\hline
\end{tabular}

Egypt. J. Hort. Vol. 41, No.1 (2014) 


\section{Results}

The effect of location, water quantity and their interaction on plant height, Table 1

Location: The effect of location on plant height was significant in both seasons. The tallest plants in the first season were those grown in the saran house, followed by those grown in the nursery, while nursery plants surpassed the saran house ones in the second season, without any significant difference in both cases. Plants grown in the lab were significantly the shortest.

Water quantity: The effect of water quantity on plant height was significant in both seasons. In the first season, plants watered with $450 \mathrm{or} 600 \mathrm{~cm}^{3} /$ pot/week were significantly taller than those irrigated with $300 \mathrm{~cm}^{3} /$ pot/week. No significant difference was detected between height of plants watered with 750 $\mathrm{cm}^{3}$ and either one of the previous two treatments. In the second season, plants irrigated with 450 or $600 \mathrm{~cm}^{3} /$ pot/week were significantly taller than those watered with either 300 or $750 \mathrm{~cm}^{3} /$ pot/week.

The interaction between location and water quantity: The effect of the interaction between location and water quantity on plant height was significant in both seasons. The tallest plants in the first season were those grown in the nursery and irrigated with either 450 or $600 \mathrm{~cm}^{3} / \mathrm{pot} / \mathrm{week}$, and those grown in saran house and watered with 450,600 or $750 \mathrm{~cm}^{3} /$ pot/week. In the second season, the tallest record in the same concern was confined to plants grown in the nursery and watered with $600 \mathrm{~cm}^{3} /$ pot/week.

The shortest plants in both seasons were those grown in the lab, irrespective of their quota of irrigation.

TABLE 1. Effect of location, water quantity and their interaction on plant height (cm).

\begin{tabular}{|l|lll|l|lcc|c|}
\hline \multirow{2}{*}{$\begin{array}{c}\text { Water } \\
\text { quantity } \\
\mathbf{c m}^{\mathbf{3}}\end{array}$} & \multicolumn{3}{|c|}{ Season 1 } & & \multicolumn{3}{c|}{ Season 2 } & \\
\cline { 2 - 9 } & Nursery & S. house & Office & Mean & Nursery & S. house & Office & Mean \\
\hline 300 & $34.10 \mathrm{bc}$ & $30.02 \mathrm{c}$ & $18.83 \mathrm{~d}$ & $27.65 \mathrm{~B}$ & $24.50 \mathrm{~d}$ & $35.36 \mathrm{bc}$ & $17.32 \mathrm{e}$ & $25.73 \mathrm{~B}$ \\
450 & $37.20 \mathrm{ab}$ & $41.00 \mathrm{a}$ & $16.90 \mathrm{~d}$ & $31.70 \mathrm{~A}$ & $38.83 \mathrm{~b}$ & $38.22 \mathrm{~b}$ & $16.35 \mathrm{e}$ & $31.13 \mathrm{~A}$ \\
600 & $41.70 \mathrm{a}$ & $40.16 \mathrm{a}$ & $14.66 \mathrm{~d}$ & $32.17 \mathrm{~A}$ & $47.42 \mathrm{a}$ & $36.84 \mathrm{~b}$ & $15.41 \mathrm{ef}$ & $33.22 \mathrm{~A}$ \\
750 & $33.60 \mathrm{bc}$ & $38.60 \mathrm{ab}$ & $14.50 \mathrm{~d}$ & $28.90 \mathrm{AB}$ & $38.87 \mathrm{~b}$ & $31.24 \mathrm{c}$ & $10.87 \mathrm{f}$ & $26.99 \mathrm{~B}$ \\
\hline Mean & $36.65 \mathrm{~A}^{\prime}$ & $37.45 \mathrm{~A}^{\prime}$ & $16.22 \mathrm{~B}^{\prime}$ & & $37.40 \mathrm{~A}^{\prime}$ & $35.42 \mathrm{~A}^{\prime}$ & $14.99 \mathrm{~B}^{\prime}$ & \\
\hline
\end{tabular}

Means having the same letter(s) at each column, row and interaction are not significantly different according to Duncan's multiple range test.

Effect of location, water quantity and their interaction on number of branches

Location: The effect of location on number of branches was significant in both seasons or as shown in Table 2. The greatest value in this concern was

Egypt. J. Hort. Vol. 41, No.1 (2014) 
a result of growing plants in the saran house, followed with a significant difference by plants grown in the nursery. The lowest number of branches belonged to plants kept in the office.

Water quantity: The effect of water quantity on number of branches was significant in both seasons. In the first season, plants watered with 300,450 or $600 \mathrm{~cm}^{3}$ water/pot/week had higher number of branches compared to those irrigated with $750 \mathrm{~cm}^{3}$ of water/pot. In the second season, the highest value in the same respect belonged to plants irrigated at $450 \mathrm{~cm}^{3} /$ pot/week, followed without significant differences by plants watered with $600 \mathrm{~cm}^{3} /$ pot/week. The lowest record in this concern was a result of using $750 \mathrm{~cm}^{3}$ of water/pot.

The interaction between location and water quantity: The significant effect of the interaction between location and water quantity on number of branches was confined to the second season only. Irrespective of the significance, it could be noticed that the greatest number of branches in both seasons was a result of keeping plants in the saran house and watering them with $450 \mathrm{~cm}^{3} /$ pot/week, while the lowest values belonged to plants grown in the office and watered with $750 \mathrm{~cm}^{3} /$ pot/week. It could also be noticed that the highest record in this regard resulted when using 600,450 and $300 \mathrm{~cm}^{3}$ water/pot/week for plants grown in the nursery, saran house and the office, respectively.

TABLE 2. Effect of location, water quantity and their interaction on number of branches.

\begin{tabular}{|c|ccc|c|ccc|c|}
\hline Water & \multicolumn{3}{|c|}{ Season 1 } & \multicolumn{3}{c|}{ Season 2 } & \\
\cline { 2 - 9 } quantity & \multicolumn{3}{|c|}{ Location } & & \multicolumn{3}{c|}{ Location } \\
$\mathbf{c m}^{\mathbf{3}}$ & Nursery & S. house & Office & Mean & Nursery & S. house & Office & Mean \\
\hline 300 & $12.20 \mathrm{a}$ & $18.60 \mathrm{a}$ & $10.00 \mathrm{a}$ & $13.60 \mathrm{~A}$ & $12.00 \mathrm{bc}$ & $13.84 \mathrm{~b}$ & $10.36 \mathrm{~cd}$ & $12.07 \mathrm{~B}$ \\
450 & $14.00 \mathrm{a}$ & $21.00 \mathrm{a}$ & $9.67 \mathrm{a}$ & $14.89 \mathrm{~A}$ & $13.40 \mathrm{~b}$ & $19.02 \mathrm{a}$ & $8.89 \mathrm{de}$ & $13.77 \mathrm{~A}$ \\
600 & $14.60 \mathrm{a}$ & $19.20 \mathrm{a}$ & $9.20 \mathrm{a}$ & $14.33 \mathrm{~A}$ & $13.78 \mathrm{~b}$ & $17.22 \mathrm{a}$ & $6.18 \mathrm{e}$ & 12.39 \\
750 & $9.20 \mathrm{a}$ & $13.00 \mathrm{a}$ & $6.60 \mathrm{a}$ & $9.60 \mathrm{~B}$ & $8.30 \mathrm{de}$ & $14.11 \mathrm{~b}$ & $2.89 \mathrm{f}$ & $8.43 \mathrm{C}$ \\
\hline Mean & $12.50 \mathrm{~B}^{\backslash}$ & $17.95 \mathrm{~A}^{\backslash}$ & $8.87 \mathrm{C}^{\backslash}$ & & $11.87 \mathrm{~B}^{\backslash}$ & $16.05 \mathrm{~A}^{\prime}$ & $7.08 \mathrm{C}^{\prime}$ & \\
\hline
\end{tabular}

Means having the same letter(s) at each column, row and interaction are not significantly different ccording to Duncan's multiple range test.

Effect of location, water quantity and their interaction on number of leaves

Location: The location where schefflera plants were grown affected number of leaves significantly in both seasons (Table 3). Plants grown in the saran house had the greatest number of leaves, while the lowest number was achieved by plants grown in the office.

Water quantity: Water quantity influenced number of leaves significantly in both seasons. The greatest record in this respect was a result of applying $450 \mathrm{~cm}^{3}$ water/pot/week. The lowest number of leaves belonged to plants irrigated with $750 \mathrm{~cm}^{3}$ water/pot/week. 
The interaction between location and water quantity: The effect of the interaction between location and water quantity on number of leaves was significant in both seasons. The greatest number of leaves was a result of using $450 \mathrm{~cm}^{3}$ water/pot/week for plants grown in the saran house. The lowest record in this respect that was common in both seasons belonged to plants kept in office and using $750 \mathrm{~cm}^{3}$ water/pot/week for irrigation. Dealing with each location individually, the highest number of leaves was obtained when 600,450 and $300 \mathrm{~cm}^{3}$ water/pot/week were used in the nursery, saran house and the office, respectively.

TABLE 3. Effect of location, water quantity and their interaction on number of leaves.

\begin{tabular}{|l|ccc|c|ccc|c|}
\hline \multirow{2}{*}{$\begin{array}{c}\text { Water } \\
\text { quantity } \\
\mathbf{c m}^{3}\end{array}$} & \multicolumn{3}{|c|}{ Season 1 } & & \multicolumn{3}{c|}{ Season 2 } & \\
\cline { 2 - 9 } & Nursery & S. house & Office & Mean & Nursery & S. house & Office & Mean \\
\hline 300 & $77.00 \mathrm{~d}$ & $120.40 \mathrm{~b}$ & $44.00 \mathrm{f}$ & $80.47 \mathrm{~B}$ & $81.83 \mathrm{c}$ & $98.04 \mathrm{~b}$ & $46.62 \mathrm{~d}$ & $75.50 \mathrm{~B}$ \\
450 & $100.80 \mathrm{c}$ & $156.40 \mathrm{a}$ & $43.67 \mathrm{f}$ & $100.29 \mathrm{~A}$ & $89.93 \mathrm{bc}$ & $129.42 \mathrm{a}$ & $43.56 \mathrm{~d}$ & $87.64 \mathrm{~A}$ \\
600 & $101.20 \mathrm{c}$ & $103.00 \mathrm{c}$ & $43.00 \mathrm{f}$ & $82.40 \mathrm{~B}$ & $97.83 \mathrm{~b}$ & $100.33 \mathrm{~b}$ & $37.40 \mathrm{~d}$ & $78.52 \mathrm{~B}$ \\
750 & $57.20 \mathrm{e}$ & $82.80 \mathrm{~d}$ & $32.60 \mathrm{f}$ & $57.53 \mathrm{C}$ & $51.02 \mathrm{~d}$ & $96.49 \mathrm{bc}$ & $12.30 \mathrm{e}$ & $53.27 \mathrm{C}$ \\
\hline Mean & $84.05 \mathrm{~B}^{\prime}$ & $115.65 \mathrm{~A}^{\prime}$ & $40.82 \mathrm{C}^{\prime}$ & & $80.15 \mathrm{~B}^{\prime}$ & $106.07 \mathrm{~A}^{\prime}$ & $34.97 \mathrm{C}^{\prime}$ & \\
\hline
\end{tabular}

Means having the same letter (s) at each column, row and interaction are not significantly different according to Duncan's multiple range test.

Effect of location, water quantity and their interaction on shoot fresh weight ( $g$ ), Table 4

Location: According to date in Table 4 the effect of location on shoot fresh weight was significant in both seasons. The heaviest fresh shoots belonged to plants grown in the saran house, while the lightest ones in the same question were plants kept in the office.

Water quantity: Water quantity affected shoot fresh weight significantly in both seasons. The heaviest shoot fresh weight was a characteristic for plants having 450 or $600 \mathrm{~cm}^{3}$ water/pot/week, followed by values of plants watered with $300 \mathrm{~cm}^{3}$ water/pot/week. The lightest plants were those having $750 \mathrm{~cm}^{3}$ water/pot/week (Table 4).

The interaction between location and water quantity: It affected shoot fresh weight significantly in both seasons. The heaviest fresh shoots were a result of watering plants grown in the saran house with either 450 or $600 \mathrm{~cm}^{3}$ water/pot/week. Plants grown in the nursery and watered with either 450 or 600 $\mathrm{cm}^{3}$ water/pot/week in the first season; or $600 \mathrm{~cm}^{3}$ water/pot/week in the second one came in the second category in the same regard. The lightest shoot fresh weight, where plants were almost dying, belonged to plants grown in the office

Egypt. J. Hort. Vol. 41, No.1 (2014) 
and watered with $750 \mathrm{~cm}^{3}$ water/pot/week. Irrespective of significance, it could be observed that irrigating plants in office, saran house and nursery with 300 , 450 and $600 \mathrm{~cm}^{3}$ water/pot/week, respectively, gave the heaviest fresh shoots in each location.

TABLE 4. Effect of location, water quantity and their interaction on shoot fresh weight $(\mathrm{g})$.

\begin{tabular}{|c|ccc|c|ccc|c|}
\hline \multirow{2}{*}{$\begin{array}{c}\text { quater } \\
\text { quantity }\end{array}$} & \multicolumn{3}{|c|}{ Season 1 } & \multicolumn{3}{c|}{ Season 2 } & \\
\cline { 2 - 9 } $\mathbf{c m}^{\mathbf{3}}$ & Nursery & S. house & Office & Mean & Nursery & S. house & Office & Mean \\
\hline 300 & $49.53 \mathrm{~cd}$ & $55.53 \mathrm{c}$ & $21.30 \mathrm{e}$ & $42.12 \mathrm{~B}$ & $57.95 \mathrm{de}$ & $64.97 \mathrm{~d}$ & $24.07 \mathrm{f}$ & $49.00 \mathrm{~B}$ \\
450 & $69.43 \mathrm{~b}$ & $85.21 \mathrm{a}$ & $18.79 \mathrm{e}$ & $57.81 \mathrm{~A}$ & $81.24 \mathrm{c}$ & $99.69 \mathrm{a}$ & $21.13 \mathrm{f}$ & $67.35 \mathrm{~A}$ \\
600 & $70.63 \mathrm{~b}$ & $79.32 \mathrm{ab}$ & $18.42 \mathrm{e}$ & $56.12 \mathrm{~A}$ & $82.64 \mathrm{bc}$ & $92.80 \mathrm{ab}$ & $20.70 \mathrm{f}$ & $65.38 \mathrm{~A}$ \\
750 & $40.47 \mathrm{~d}$ & $45.16 \mathrm{~cd}$ & $7.00 \mathrm{f}$ & $30.88 \mathrm{C}$ & $47.35 \mathrm{e}$ & $52.84 \mathrm{e}$ & $7.34 \mathrm{~g}$ & $35.85 \mathrm{C}$ \\
\hline Mean & $57.52 \mathrm{~B}$ & $66.30 \mathrm{~A}^{\prime}$ & $16.38 \mathrm{C}$ & & $67.29 \mathrm{~B}^{\prime}$ & $77.58 \mathrm{~A}^{\prime}$ & $18.31 \mathrm{C}$ & \\
\hline
\end{tabular}

Means having the same letter(s) at each column, row and interaction are not significantly different according to Duncan's multiple range test.

Effect of location, water quantity and their interaction on shoot dry weight $(\mathrm{g})$

Location: The effect of location on shoot dry weight was significant in both seasons. The heaviest dry shoots were those grown in the saran house in both years and those grown in the nursery in the second season only. The lowest value in this respect was a result of keeping plants in the office (Table 5).

Water quantity: Water quantity significantly affected shoot dry weight in both seasons. The heaviest dry shoots belonged to plants watered with either 450 or $600 \mathrm{~cm}^{3}$ water/pot/week. The lowest record in this concern was a result of irrigating with $750 \mathrm{~cm}^{3}$ water/pot/week in both seasons or with $300 \mathrm{~cm}^{3}$ water/pot/week in the second season.

The interaction between location and water quantity: The significant effect of the interaction between location and water quantity on shoot dry weight was confined to the first season only. However, the heaviest dry shoots were a result of applying either 450 or $600 \mathrm{~cm}^{3}$ water/pot/week for plants grown in the saran house. The lowest value in this concern belonged to plants kept in the office and watered with $750 \mathrm{~cm}^{3}$ water/pot/week, which led plants almost to death. Dealing with each location separately, it could be noticed that applying 600, 450 and $300 \mathrm{~cm}^{3}$ water/pot/week was the best for plants in the nursery, saran house and office, respectively. 
TABLE 5. Effect of location, water quantity and their interaction on shoot dry weight $(\mathrm{g})$.

\begin{tabular}{|c|ccc|c|ccc|c|}
\hline $\begin{array}{c}\text { Water } \\
\text { quantity } \\
\mathbf{c m}^{\mathbf{3}}\end{array}$ & \multicolumn{3}{|c|}{ Season 1 } & \multicolumn{3}{c|}{ Season 2 } & \multicolumn{3}{c|}{$\begin{array}{c}\text { Location } \\
\text { Sursery }\end{array}$} & S. house & Office & Mean & Nursery & Souse & Office & Mean \\
\hline 300 & $14.40 \mathrm{~d}$ & $13.00 \mathrm{de}$ & $5.24 \mathrm{f}$ & $10.88 \mathrm{~B}$ & $16.84 \mathrm{bc}$ & $15.21 \mathrm{bc}$ & $5.79 \mathrm{~d}$ & $12.61 \mathrm{~B}$ \\
450 & $17.07 \mathrm{c}$ & $21.96 \mathrm{a}$ & $4.70 \mathrm{f}$ & $14.58 \mathrm{~A}$ & $19.97 \mathrm{a}-\mathrm{c}$ & $25.70 \mathrm{a}$ & $5.15 \mathrm{~d}$ & $16.94 \mathrm{~A}$ \\
600 & $18.83 \mathrm{bc}$ & $20.25 \mathrm{ab}$ & $4.52 \mathrm{fg}$ & $14.53 \mathrm{~A}$ & $22.03 \mathrm{ab}$ & $23.69 \mathrm{a}$ & $4.94 \mathrm{~d}$ & $16.89 \mathrm{~A}$ \\
750 & $12.24 \mathrm{e}$ & $11.24 \mathrm{e}$ & $2.75 \mathrm{~g}$ & $8.74 \mathrm{C}$ & $14.32 \mathrm{c}$ & $13.39 \mathrm{c}$ & $2.88 \mathrm{~d}$ & $10.19 \mathrm{~B}$ \\
\hline Mean & $15.63 \mathrm{~B}^{\backslash}$ & $16.62 \mathrm{~A}^{\backslash}$ & $4.30 \mathrm{C}^{\backslash}$ & & $18.29 \mathrm{~A}^{\backslash}$ & $19.50 \mathrm{~A}^{\backslash}$ & $4.69 \mathrm{~B}^{\backslash}$ & \\
\hline
\end{tabular}

Means having the same letter(s) at each column, row and interaction are not significantly different according to Duncan's multiple range test.

Effect of location, water quantity and their interaction on root length

Location: The effect of location on root length was significant in both seasons as shown as Table 6 . The longest roots were a result of growing plants in the nursery, followed with a significant difference with those grown in the saran house. The shortest roots belonged to plants grown in the office.

Water quantity: Water quantity affected root length significantly in both seasons. Roots were longer when 300,450 or $600 \mathrm{~cm}^{3}$ water/pot/week was used, compared to the corresponding record when using $750 \mathrm{~cm}^{3}$ water/pot/week.

The interaction between location and water quantity: It was significant in both seasons. The longest roots belonged to plants grown in the nursery and watered with 300,450 or $600 \mathrm{~cm}^{3}$ water/pot/week and those grown in the saran house and watered with $450 \mathrm{~cm}^{3}$ water/pot/week, in both seasons, in addition to plants grown in the nursery and the saran house and watered with 750 or $600 \mathrm{~cm}^{3}$ water/pot/week, respectively, in the second season only. The shortest roots were a result of keeping plants in the office and watering them with either $750 \mathrm{~cm}^{3}$ water/pot/week in both seasons or with $600 \mathrm{~cm}^{3}$ water/pot/week in the second season only.

TABLE 6. Effect of location, water quantity and their interaction on root length $(\mathrm{cm})$.

\begin{tabular}{|c|ccc|c|ccc|c|}
\hline Water & \multicolumn{3}{|c|}{ Season 1 } & \multicolumn{3}{c|}{ Season 2 } & \\
\cline { 2 - 9 } $\begin{array}{c}\text { quantity } \\
\mathbf{c m}^{\mathbf{3}}\end{array}$ & Nursery & S. house & Office & Mean & Nursery & S. house & Office & Mean \\
\hline 300 & $50.40 \mathrm{ab}$ & $34.40 \mathrm{c}$ & $23.26 \mathrm{~d}$ & $36.02 \mathrm{~A}$ & $58.97 \mathrm{a}$ & $40.25 \mathrm{~b}$ & $26.36 \mathrm{c}$ & $41.86 \mathrm{~A}$ \\
450 & $53.00 \mathrm{ab}$ & $50.30 \mathrm{ab}$ & $17.10 \mathrm{de}$ & $40.13 \mathrm{~A}$ & $62.01 \mathrm{a}$ & $62.13 \mathrm{a}$ & $19.16 \mathrm{~cd}$ & $47.76 \mathrm{~A}$ \\
600 & $56.90 \mathrm{a}$ & $47.70 \mathrm{~b}$ & $12.92 \mathrm{ef}$ & $39.17 \mathrm{~A}$ & $66.57 \mathrm{a}$ & $55.81 \mathrm{a}$ & $14.27 \mathrm{~d}$ & $45.55 \mathrm{~A}$ \\
750 & $47.20 \mathrm{~b}$ & $35.50 \mathrm{c}$ & $7.50 \mathrm{f}$ & $30.07 \mathrm{~B}$ & $55.22 \mathrm{a}$ & $41.54 \mathrm{~b}$ & $7.93 \mathrm{~d}$ & $34.89 \mathrm{~B}$ \\
\hline Mean & $51.88 \mathrm{~A}^{\prime}$ & $41.98 \mathrm{~B}^{\backslash}$ & $15.20 \mathrm{C}^{\prime}$ & & $60.69 \mathrm{~A}^{\prime}$ & $49.93 \mathrm{~B}^{\backslash}$ & $16.93 \mathrm{C}^{\prime}$ & \\
\hline
\end{tabular}

Means having the same letter(s) at each column, row and interaction are not significantly different according to Duncan's multiple range test.

Egypt. J. Hort. Vol. 41, No.1 (2014) 
Effect of location, water quantity and their interaction on root fresh weight $(g)$

Location: The effect of location on root fresh weight was significant in both seasons. The heaviest fresh roots belonged to plants grown in the nursery, followed with a significant difference by those grown in the nursery. The lightest fresh roots were a result of keeping plants in the office (Table 7).

Water quantity: Water quantity exerted a significant influence on root fresh weight in both seasons. The heaviest fresh roots were observed on plants watered with either 600 or $450 \mathrm{~cm}^{3}$ water/pot/week in the first and second seasons, respectively. The lightest fresh roots were induced when $750 \mathrm{~cm}^{3}$ water/pot/week were used in both seasons.

The interaction between location and water quantity: The interaction between location and water quantity affected root fresh weight significantly in both seasons. The heaviest fresh roots belonged to plants grown in the nursery and watered with either 600 or $450 \mathrm{~cm}^{3}$ water/pot/week in the first and second seasons, respectively. The lightest fresh roots were a result of keeping plants in the office and irrigating them with either one of the different watering regimes in the first season, or with $750 \mathrm{~cm}^{3}$ water/pot/week in the second one.

TABLE 7. Effect of location, water quantity and their interaction on root fresh weight $(\mathrm{g})$.

\begin{tabular}{|c|ccc|c|ccc|c|}
\hline $\begin{array}{c}\text { Water } \\
\text { quantity } \\
\mathbf{c m}^{\mathbf{3}}\end{array}$ & \multicolumn{3}{|c|}{ Season 1 } & \multicolumn{3}{c|}{ Season 2 } & \multicolumn{3}{c|}{ Location } \\
\cline { 2 - 8 } & Nursery & S. house & Office & Mean & Nursery & S. house & Office & Mean \\
\hline 300 & $26.89 \mathrm{bc}$ & $18.78 \mathrm{~d}$ & $5.84 \mathrm{f}$ & $17.17 \mathrm{C}$ & $31.46 \mathrm{bc}$ & $21.97 \mathrm{~cd}$ & $7.17 \mathrm{ef}$ & $\begin{array}{c}20.20 \\
\text { BC }\end{array}$ \\
450 & $28.92 \mathrm{~b}$ & $25.44 \mathrm{bc}$ & $6.42 \mathrm{f}$ & $20.26 \mathrm{~B}$ & $53.27 \mathrm{a}$ & $29.77 \mathrm{bc}$ & $6.59 \mathrm{ef}$ & $29.88 \mathrm{~A}$ \\
600 & $45.53 \mathrm{a}$ & $23.69 \mathrm{c}$ & $5.92 \mathrm{f}$ & $25.05 \mathrm{~A}$ & $33.84 \mathrm{~b}$ & $27.72 \mathrm{bc}$ & $6.49 \mathrm{ef}$ & $22.68 \mathrm{~B}$ \\
750 & $24.95 \mathrm{bc}$ & $12.33 \mathrm{e}$ & $2.98 \mathrm{f}$ & $13.42 \mathrm{D}$ & $29.19 \mathrm{bc}$ & $14.42 \mathrm{de}$ & $3.14 \mathrm{f}$ & $15.59 \mathrm{C}$ \\
\hline Mean & $31.57 \mathrm{~A}^{\prime}$ & $20.06 \mathrm{~B}$ & $5.29 \mathrm{C}^{\prime}$ & & $36.94 \mathrm{~A}^{\prime}$ & $23.47 \mathrm{~B}$ & $5.85 \mathrm{C}$ & \\
\hline
\end{tabular}

Means having the same letter(s) at each column, row and interaction are not significantly different according to Duncan's multiple range test.

Effect of location, water quantity and their interaction on root dry weight $(g)$

Location: Results in Table 8 revealed that the effect of location on root dry weight was significant in both seasons. The heaviest dry roots belonged to plants grown in the nursery, followed with a significant difference by those grown in the nursery. The lightest dry roots were a result of keeping plants in the office.

Water quantity: Water quantity affected root dry weight significantly in both seasons. The heaviest dry roots belonged to plants irrigated with $600 \mathrm{~cm}^{3}$ water/pot/week, followed with a significant difference by those having either 300 or $450 \mathrm{~cm}^{3}$ water/pot/week. The lowest record in this respect was a result of applying $600 \mathrm{~cm}^{3}$ water/pot/week. 
The interaction between location and water quantity: The effect of the interaction between location and water quantity affected root dry weight was significant in both seasons. The heaviest dry roots were induced on plants grown in the nursery and watered with $600 \mathrm{~cm}^{3}$ water/pot/week. The second category was occupied by plants grown in the saran house and watered with either 450 or $600 \mathrm{~cm}^{3}$ water/pot/week in both seasons, plants grown in the nursery and irrigated with 300,450 or $750 \mathrm{~cm}^{3}$ water/pot/week, and plants grown the saran house and watered with $300 \mathrm{~cm}^{3}$ water/pot/week, in the second season only. The lightest root dry weight was observed in plants kept in the office and received $750 \mathrm{~cm}^{3}$ water/pot/week in both seasons, in addition to plants kept in the office and watered with 300,450 or $600 \mathrm{~cm}^{3}$ water/pot/week in the second season only.

TABLE 8. Effect of location, water quantity and their interaction on root dry weight (g).

\begin{tabular}{|c|ccc|c|ccc|c|}
\hline \multirow{2}{*}{$\begin{array}{c}\text { Water } \\
\text { quantity }\end{array}$} & \multicolumn{3}{|c|}{ Season 1 } & \multicolumn{3}{c|}{ Season 2 } & \\
\cline { 2 - 9 } $\mathbf{c m}^{3}$ & Nursery & S. house & Office & Mean & Nursery & S. house & Office & Mean \\
\hline 300 & $5.39 \mathrm{~cd}$ & $5.24 \mathrm{~d}$ & $1.88 \mathrm{ef}$ & $4.17 \mathrm{~B}$ & $6.31 \mathrm{~b}$ & $6.13 \mathrm{~b}$ & $2.03 \mathrm{c}$ & $4.83 \mathrm{BC}$ \\
450 & $5.46 \mathrm{~cd}$ & $7.36 \mathrm{~b}$ & $1.90 \mathrm{ef}$ & $4.91 \mathrm{~B}$ & $6.39 \mathrm{~b}$ & $8.62 \mathrm{~b}$ & $2.06 \mathrm{c}$ & $5.69 \mathrm{~B}$ \\
600 & $13.46 \mathrm{a}$ & $6.69 \mathrm{bc}$ & $1.64 \mathrm{ef}$ & $7.26 \mathrm{~A}$ & $15.75 \mathrm{a}$ & $7.83 \mathrm{~b}$ & $1.75 \mathrm{c}$ & $8.44 \mathrm{~A}$ \\
750 & $5.37 \mathrm{~cd}$ & $2.77 \mathrm{e}$ & $1.27 \mathrm{f}$ & $3.14 \mathrm{C}$ & $6.28 \mathrm{~b}$ & $3.24 \mathrm{c}$ & $1.31 \mathrm{c}$ & $3.61 \mathrm{C}$ \\
\hline Mean & $7.42 \mathrm{~A}^{\prime}$ & $5.52 \mathrm{~B}^{\prime}$ & $1.67 \mathrm{C}^{\prime}$ & & $8.68 \mathrm{~A}^{\prime}$ & $6.46 \mathrm{~B}^{\prime}$ & $1.79 \mathrm{C}^{\prime}$ & \\
\hline
\end{tabular}

Means having the same letter(s) at each column, row and interaction are not significantly different according to Duncan's multiple range test.

Effect of location, water quantity and their interaction on leaf content of total carbohydrates ( $\mathrm{mg} / \mathrm{g}$ d.wt.)

Location: Plants grown in the nursery had the highest leaf content of total carbohydrates, followed by plants grown in the saran house. The lowest content in the same respect was found in the leaves of plants kept in the office (Table 9).

Water quantity: plants irrigated with 450 or $600 \mathrm{~cm}^{3}$ water/pot/week in both seasons, in addition to those irrigated with $300 \mathrm{~cm}^{3}$ water/pot/week in the first season, obtained the highest leaf content of total carbohydrates. The lowest record in this regard belonged to plants watered with $750 \mathrm{~cm}^{3}$ water/pot/week in both seasons.

The interaction between location and water quantity: The highest leaf content of total carbohydrates was a result of using $600 \mathrm{~cm}^{3}$ water/pot/week, followed by plants received $450 \mathrm{~cm}^{3}$ water/pot/week, for plants grown in the nursery in both seasons. The lowest value of leaf content of total carbohydrates was observed in plants kept in the office and irrigated with $750 \mathrm{~cm}^{3}$ water/ pot/ week in both seasons. 
TABLE 9. Effect of location, water quantity and their interaction on leaf content of total carbohydrates (mg/g d.wt.).

\begin{tabular}{|c|ccc|c|ccc|c|}
\hline \multirow{2}{*}{\begin{tabular}{c} 
Water \\
quantity \\
\cline { 2 - 9 }
\end{tabular}} & \multicolumn{3}{|c|}{ Season 1 } & \multicolumn{3}{c|}{ Season 2 } & \\
cm $^{\mathbf{3}}$ & Nursery & S. house & Office & Mean & Nursery & S. house & Office & Mean \\
\hline 300 & 294.23 & 299.79 & 247.57 & 280.53 & 290.25 & 319.92 & 272.32 & 294.17 \\
450 & 306.02 & 302.79 & 232.95 & 280.59 & 323.65 & 333.07 & 250.65 & 302.46 \\
600 & 315.14 & 296.90 & 229.60 & 280.55 & 341.64 & 319.92 & 240.28 & 300.61 \\
750 & 294.24 & 284.78 & 226.14 & 268.38 & 318.00 & 300.27 & 235.29 & 284.52 \\
\hline Mean & 302.41 & 296.07 & 234.06 & & 318.39 & 318.30 & 249.64 & \\
\hline
\end{tabular}

Effect of location, water quantity and their interaction on stem content of total carbohydrates ( $m g / g$ d.wt.)

Location: As shown in Table 10 Plants grown in the nursery had the highest stem content of total carbohydrates, followed by the content of plants raised in the saran house. The lowest content in the same respect was found in plants located in the office as an ornament.

Water quantity: plants watered with $450 \mathrm{~cm}^{3}$ water/pot/week in both seasons, in addition to those irrigated with $300 \mathrm{~cm}^{3}$ water/pot/week in the first season, obtained the highest stem content of total carbohydrates. The lowest record in this respect belonged to plants irrigated with $750 \mathrm{~cm}^{3}$ water/pot/week in both seasons.

The interaction between location and water quantity: The highest stem content of total carbohydrates was a result of using $600 \mathrm{~cm}^{3}$ water/pot/week for plants grown in the nursery in both seasons. The lowest value was observed in plants kept in the office and irrigated with $750 \mathrm{~cm}^{3}$ water/pot/week in both seasons.

TABLE 10. Effect of location, water quantity and their interaction on stem content of total carbohydrates (mg/g d.wt.).

\begin{tabular}{|c|ccc|c|ccc|c|}
\hline \multirow{2}{*}{\begin{tabular}{c} 
Water \\
quantity \\
\cline { 2 - 9 } $\mathbf{c m}^{\mathbf{3}}$
\end{tabular}} & \multicolumn{3}{|c|}{ Season 1 } & \multicolumn{3}{c|}{ Season 2 } & \\
\hline 300 & 282.67 & 253.53 & 232.36 & 256.19 & 307.63 & 297.90 & 255.60 & 287.04 \\
450 & 279.66 & 288.11 & 213.06 & 260.28 & 310.94 & 313.26 & 234.36 & 286.19 \\
600 & 292.90 & 284.78 & 188.06 & 255.25 & 322.19 & 297.90 & 206.86 & 275.65 \\
750 & 264.10 & 251.31 & 113.42 & 209.61 & 290.51 & 276.44 & 124.77 & 230.57 \\
\hline Mean & 279.83 & 269.43 & 186.72 & & 307.82 & 296.38 & 205.40 & \\
\hline
\end{tabular}


Effect of location, water quantity and their interaction on leaf content of total chlorophyll ( $\mathrm{mg} / \mathrm{g}$ f.wt.)

Location: Data in Table 11 revealed that the highest content of total chlorophyll was a result of growing plants in the nursery, while those grown in the saran house came in the second category. The lowest record in this regard belonged to plants kept in the office.

Water quantity: The highest content of total chlorophyll was induced by irrigation with $600 \mathrm{~cm}^{3}$ water/pot/week, followed by the corresponding content observed when $450 \mathrm{~cm}^{3}$ water/pot/week were used for irrigation, in the first season. An opposite situation occurred in the second season, where the first and second positions were occupied by plants having 450 and $600 \mathrm{~cm}^{3}$ water/pot/ week, respectively.

The interaction between location and water quantity: The highest content of leaf total chlorophyll was a result of using either $600 \mathrm{~cm}^{3}$ water/pot/week for plants grown in the nursery or 450 water/pot/week for plants grown in the saran house, in the first and second seasons, respectively. The second rank was occupied by plants watered with 450 water/pot/week for plants grown in the saran house, or those watered with 600 water/pot/week for plants grown in the nursery, in the first and second seasons, respectively. The lowest content of total chlorophyll in both seasons was confined to plants kept in the office and irrigated with 750 water/pot/week.

TABLE 11. Effect of location, water quantity and their interaction on leaf content of total chlorophyll (mg/g f.wt.).

\begin{tabular}{|c|ccc|c|ccc|c|}
\hline Water & \multicolumn{3}{|c|}{ Season 1 } & & \multicolumn{3}{c|}{ Season 2 } & \\
\cline { 2 - 10 } quantity & \multicolumn{3}{|c|}{ Location } & & \multicolumn{3}{c|}{ Location } \\
$\mathbf{c m}^{3}$ & Nursery & S. house & Office & Mean & Nursery & S. house & Office & Mean \\
\hline 300 & 0.69 & 0.60 & 0.83 & 0.71 & 0.84 & 0.74 & 0.90 & 0.83 \\
450 & 0.70 & 0.99 & 0.78 & 0.82 & 0.98 & 1.09 & 0.62 & 0.89 \\
600 & 1.32 & 0.80 & 0.61 & 0.91 & 1.07 & 0.88 & 0.61 & 0.85 \\
750 & 0.65 & 0.75 & 0.59 & 0.66 & 0.98 & 0.74 & 0.57 & 0.76 \\
\hline Mean & 0.84 & 0.78 & 0.70 & & 0.97 & 0.86 & 0.67 & \\
\hline
\end{tabular}

Effect of location, water quantity and their interaction on leaf content of carotenoids ( $m g / g$ f.wt.)

Location: As shown in Table 12 the highest content of carotenoids was found in plants grown in the nursery, followed by plants grown in the saran house. The lowest record in this respect was observed in plants kept in the office.

Water quantity: The highest content of carotenoids was obtained by irrigation with $600 \mathrm{~cm}^{3}$ water/pot/week, followed by the corresponding content observed when $450 \mathrm{~cm}^{3}$ water/pot/week was used, in the first season. On the contrary, an

Egypt. J. Hort. Vol. 41, No.1 (2014) 
opposite situation occurred in the second season, where the first and second categories were occupied by plants having 450 and $600 \mathrm{~cm}^{3}$ water/pot/week, respectively. The lowest content in both seasons was a result of using $750 \mathrm{~cm}^{3}$ water/pot/week.

The interaction between location and water quantity: The highest content of carotenoids was found in plants grown in the nursery and irrigated with $600 \mathrm{~cm}^{3}$ water/pot/week, followed by plants grown in the saran house and irrigated with $450 \mathrm{~cm}^{3}$ water/pot/week. The lowest content in both seasons was a result of using $750 \mathrm{~cm}^{3}$ water/pot/week for plants kept in the office.

TABLE 12. Effect of location, water quantity and their interaction on leaf content of carotenoids (mg/g f.wt.).

\begin{tabular}{|c|ccc|c|ccc|c|}
\hline Water & \multicolumn{3}{|c|}{ Season 1 } & & \multicolumn{3}{c|}{ Season 2 } & \\
\cline { 2 - 10 } quantity & \multicolumn{3}{|c|}{ Location } & & \multicolumn{3}{c|}{ Location } & \\
$\mathbf{c m}^{3}$ & Nursery & S. house & Office & Mean & Nursery & S. house & Office & Mean \\
\hline 300 & 0.16 & 0.20 & 0.22 & 0.19 & 0.21 & 0.24 & 0.24 & 0.23 \\
450 & 0.28 & 0.29 & 0.16 & 0.24 & 0.31 & 0.32 & 0.17 & 0.27 \\
600 & 0.34 & 0.28 & 0.14 & 0.26 & 0.38 & 0.26 & 0.16 & 0.27 \\
750 & 0.23 & 0.16 & 0.07 & 0.15 & 0.21 & 0.19 & 0.08 & 0.16 \\
\hline Mean & 0.25 & 0.23 & 0.15 & & 0.28 & 0.25 & 0.16 & \\
\hline
\end{tabular}

\section{Discussion}

In the current study, three locations (the nursery, the saran house and the office) and 4 amounts of water (300, 450, 600 and $750 \mathrm{~cm}^{3} /$ pot/week) for irrigating Schefflera arboricola plants were compared. The best watering amounts to be used in each location in order to obtain the best ornamental characters, could be deduced as follows: The highest values of plant height, number of branches, number of leaves, shoot fresh and dry weights were achieved when 600,450 or $300 \mathrm{~cm}^{3} /$ pot/week were used to irrigate plants in the nursery, the saran house and the office, respectively.

Differences in growth parameters between plants grown in the nursery or the saran house or kept for ornamentation in the office might be attributed to differences between these three locations in light intensity and temperature. Generally, low light intensities, typical for indoors, reduce leaf quality (Conover \& Poole, 1977 and Sawwan \& Ghunem, 1999). However, there are differences among species grown under low light intensities. For example, when grown in shade, the fresh and dry weights of Peperomia obtusifolia increased (Shen and Seeley, 1983), but dry weight of Ficus benjamina was reduced (Collins and Blessington, 1982). The fresh weight of Hedera helix was 
unaffected by light intensity (Collins and Blessington, 1981), whereas when $F$. benjamina and Chamaedorea elegans were grown in shade, leaves had higher chlorophyll content than leaves of plants grown in the sun (Lance \& Guy, 1992 and Reyes et al. 1996). The leaf thickness of Pelargonium $\times$ hortorum was reduced by increasing temperatures from $10^{\circ} \mathrm{C}$ to $32^{\circ} \mathrm{C}$ (Armitage et al. 1981). In contrast, temperature had no significant influence on leaf thickness and mesophyll parenchyma of $F$. benjamina (Kubatsch et al. 2005). In addition, the temperature optimum for growth parameters decreased as light intensity decreased (Björkman, 1980). High growth temperatures resulted in reduced light absorption rates because of thin palisade mesophyll parenchyma, and resulted in lower net photosynthetic rates (low dry matter production) in Pelargonium $\times$ hortorum (Armitage et al. 1981). The assimilation rate of Euphorbia pulcherrima and Chrysanthemum grandiflorum increased with raising temperature levels resulting from higher light absorption (Menne, 1992). Kubatsch et al. (2007) held Schefflera arboricola in light- and temperature-controlled chambers for 6 months under three light intensities of 10,20 and $80 \mu \mathrm{mol} \cdot \mathrm{m}^{-2} \cdot \mathrm{s}^{-1}$ and three temperature regimes: 15,20 and $25^{\circ} \mathrm{C}$. They found that reduced light intensity significantly decreased fresh and dry weight and increased chlorophyll content. High temperatures reduced fresh weight and significantly increased chlorophyll content.

The effect of humidity was also mentioned by some authors. Mortensen (1986) grew young plants of some different greenhouse species at 55-60, 70-75 or 90$95 \%$ relative humidity $(\mathrm{RH})$ in growth rooms. He remarked that the dry weight increased significantly by increasing RH from the lowest to the highest level in Begonia hiemalis, Saintpaulia ionantha, Euphorbia pulche-rrima, Chrysanthemum morifolium and Nephrolepis exaltata. The dry weight of Campanula isophylla and Rosa was not affected by RH, while Soleirolia soleirolii was negatively affected. Shoot length increased very considerably by raising the RH in most of the species. The number of leaves increased by RH in some of the species while not in others. Mortensen and Gislerød (1990) studied the effects of relative air humidity (RH) in 23 foliage species at $24^{\circ} \mathrm{C}$ air temperature during winter. They found that increasing the RH from 60 to $85 \%$ significantly increased the dry weight in four species and decreased it in one. Plant height increased in five species when the RH level was raised, while dry weight and/or height were affected by RH in nine out of the 23 species. Six of the species developed a lighter green color at high RH compared with low RH.

Many conflicting arguments could be found in the literature concerning irrigation. Some authors claimed that higher levels of watering are in favor of plant height. For example, El-Shakhs et al. (2002) on Dahlia pinnata stated that increasing quantity of water improved plant height. Chylinski et al. (2007) found that in impatiens (Impatiens walleriana) grown at 30\% of soil water content, plant height was reduced by drought as compared to those grown at $80 \%$ of soil water content. Kazaz et al. (2010) determined the effects of different irrigation water amounts $(0.25,0.50,0.75,1.00$ and 1.25 crop-pan coefficients "kcp") on carnation plants (Dianthus caryophyllus cv. 'Turbo') grown in soil under greenhouse

Egypt. J. Hort. Vol. 41, No.1 (2014) 
conditions. They observed that the significantly longest stems were determined in 1.25 and $1.00 \mathrm{kcp}$. Singh (2011) found that the increase in irrigation level (from18.1 to 20.2, 26.5 and $36.2 \mathrm{~mm} /$ plant) enhanced height one-year-old Eucalyptus camaldulensis plants. This variable was highest at $36.2 \mathrm{~mm}$. Álvarez et al. (2013) subjected Pelargonium $\times$ hortorum plants to irrigation treatments: control (100\% water field capacity) and deficit irrigation (75\% water field capacity). They indicated that plant height depends on the amount of water applied.

However, many workers postulated that privileges of the moderate level of irrigation surpassed that of higher ones as mentioned by Nada et al. (1992) on Iris, Mortimer et al (2003) on Protea hybrida Sylvia, and El-Hanafy et al. (2006) on Ornithogalum thyrsoides. In addition, ShuMing et al. (2008) determined growth indices of six-year-old Eucommia ulmoides stump plants under different water conditions $\left(0.14,0.28,0.42\right.$ and $\left.0.56 \mathrm{~m}^{3}\right)$ during the growing season. They found that the optimum irrigation norm was $0.42 \mathrm{~m}^{3}$ per tree, where the length of second ramification was the most. Blanusa and Cameron (2009) irrigated Plants of Petunia hybrida cv. Hurrah White and Impatiens cv. Cajun Violet in 2-litre containers daily under a 25 or $100 \%$ watering regime. They noticed that a decrease in substrate moisture content to around $0.1 \mathrm{~m}^{3} / \mathrm{m}^{3}$ (from day 12) under the $25 \%$ watering regime reduced plant size in both species. El-Boraie et al. (2009) conducted an experiment to elucidate the optimizing irrigation schedule to maximize water use efficiency of roselle, Hibiscus sabdariffa, applying five irrigation water quantities, $60 \%, 80 \%, 100 \%, 120 \%$ and $140 \%$ of the potential evapotranspiration (ETm). They concluded that irrigation water schedule $80 \%$ ETm produced the highest plants, the lowest at $60 \%$ of the same criterion. Lucia (2009) studied the irrigation container-grown ornamental shrubs Eremophila glabra and E. nivea at $100 \%$ (control: optimal regime), $50 \%$ and $0 \%$ (reduced regimes: stress) of the evapotranspired water. He found that irrigation values close to $50 \%$ of ETo would be enough to maintain the ornamental values such as plant height. Garas (2011) found that supplying some Hibiscus rosa-sinensis cultivars with the moderate irrigation level $(0.75 \mathrm{~L} /$ pot $)$ was the best for increasing plant height, compared to the other irrigation two levels. Meanwhile, applying the highest level (1 L/pot) occupied the second rank in the same regard.

On the contrary, Fox and Montague (2009) stated that for Cercis canadensis, shoot elongation was generally greatest for trees that received lower irrigation treatments. For Acer (A. campestre, A. freemanii and A. truncatum) and Quercus ( $Q$. muehlenbergii and $Q$. robur), shoot elongation varied with irrigation level. Despite the three differing irrigation volumes, greatest growth was not always associated with increased irrigation volume.

Although Scheiber et al. (2008) observed that irrigation quantity did not affect final height or growth indices of Solenostemon scutellarioides (coleus), both Hansen \& Petersen (2004) and D'souza \& Devaraj (2011) found that drought stress reduced plant height of Hibiscus rosa-sinensis and Dolichos lablab (HA-4 cultivar), respectively. 
The effect of irrigation amount level on number of branches was discussed by many workers. High level of watering was preferred in some papers. El-Shakhs et al. (2002) on Dahlia pinnata stated that increasing quantity of water improved number of branches/plant. Garas (2011) reported that using the highest irrigation level $(1 \mathrm{~L} / \mathrm{pot})$ for some Hibiscus rosa-sinensis cultivars was the best for increasing number of branches/plant.

However, the intermediate watering amount gave better results in this regard as mentioned by ShuMing et al. (2008) who determined growth indices of sixyear-old Eucommia ulmoides stump plants under different water conditions $\left(0.14,0.28,0.42\right.$ and $\left.0.56 \mathrm{~m}^{3}\right)$ during the growing season. They found that the optimum irrigation norm was $0.42 \mathrm{~m}^{3}$ per tree, where the number second ramification was the most. Lucia (2009) found that irrigation values close to $50 \%$ of ET0 would be enough to maintain the ornamental values such as number of shoots of container-grown ornamental shrubs Eremophila glabra and E. nivea.

On the contrary, Fascella et al. (2011) observed that plants of two potted Euphorbia x lomi hybrids ('Nam Chok' and 'Udom Sab') with deficit irrigation produced more flowering stems than control plants.

In regard to the effect of watering amounts on number of leaves, many authors noticed that water deficit associated with increasing soil moisture tension led to deterioration in number of leaves produced by plant. D'souza and Devaraj (2011) found that drought stress reduced leaf number of Dolichos lablab (HA-4 cultivar).

The positive effect of applying the highest irrigation level in increasing number of leaves was mentioned by various authors such as El-Hanafy et al. (2006) on Ornithogalum thrysoides and El-Shakhs et al. (2002) on Dahlia pinnata stated that increasing quantity of water improved number of leaves/plant. Garas (2011) reported that the greatest number of leaves/plant of some Hibiscus rosa-sinensis cultivars was registered when applying the highest irrigation level (1 L/pot).

However, Lucia (2009) found that irrigation values close to $50 \%$ of ET0 would be enough to maintain the ornamental values of container-grown ornamental shrubs Eremophila glabra and E. nivea such as number of leaves.

The major impact of irrigation amount might be its effect on weight of the vegetative growth of the plant. Using higher amounts of water was beneficial to some plants. Stabler and Martin (2004) reported that the greatest total biomass production of two landscape shrubs, Nerium oleander 'Sister Angus' and Leucophyllum frutescens var. Green Cloud occurred for shrubs receiving high irrigation volumes. Kafi et al. (2010) subjected Kochia (Kochia scoparia) cvs. Sabzevar and Borujerd, to four irrigation regimes, 100, 80, 60, and $40 \%$ of the water requirements. They found that the highest biomass was obtained from

Egypt. J. Hort. Vol. 41, No.1 (2014) 
complete irrigation (100\%). Kazaz et al. (2010) determined the effects of different irrigation water amounts $(0.25,0.50,0.75,1.00$ and 1.25 crop-pan coefficients "kcp") on carnation plants (Dianthus caryophyllus cv. 'Turbo') grown in soil under greenhouse conditions. They observed that the significantly highest stem fresh weight was determined in 1.25 and $1.00 \mathrm{kcp}$. Singh (2011) provided one-year-old Eucalyptus camaldulensis plants with supplemental irrigation at $36.2,26.5,20.2,18.1 \mathrm{~mm} /$ plant, and life saving irrigation. They found that the increase in irrigation level enhanced dry biomass. This variable was highest at $36.2 \mathrm{~mm}$.

However, other workers found that moderate watering amounts were more preferable. Mortimer et al. (2003) exposed Protea hybrida Sylvia (Protea susannae $\mathrm{x}$ Protea eximia) plants in glasshouse to watering regimes maintaining water at 20,40 and 60\% of field capacity in sand-filled pots. They found that higher water supply resulted in increased growth of the shoots, reaching a maximum at $40 \%$ of field capacity. ShuMing et al. (2008) determined growth indices of six-year-old Eucommia ulmoides stump plants under different water conditions $\left(0.14,0.28,0.42\right.$ and $0.56 \mathrm{~m}^{3} /$ plant $)$ during the growing season. They found that the optimum irrigation norm was $0.42 \mathrm{~m}^{3} /$ plant, where the dry weight of the leaves was greater. El-Boraie et al. (2009) conducted an experiment to elucidate the optimizing irrigation schedule to maximize water use efficiency of roselle, Hibiscus sabdariffa, applying five irrigation water quantities, $60 \%, 80 \%$, $100 \%, 120 \%$ and $140 \%$ of the potential evapotranspiration (ETm). They concluded that the most effective treatment on increasing the fresh and dry weight of leaves, stems, roots and whole plant, was 100\% ETm. Lucia (2009) studied the irrigation container-grown ornamental shrubs Eremophila glabra and E. nivea at $100 \%$ (control: optimal regime), $50 \%$ and $0 \%$ (reduced regimes: stress) of the evapotranspired water. He found that irrigation values close to $50 \%$ of ET0 would be enough to maintain the ornamental values such as total fresh and dry weights. In this way, a considerable saving in water could be promoted. Iersel et al. (2010) determined how different substrate volumetric water contents (theta) affected petunia (Petunia $\mathrm{x}$ hybrida) growth. Irrigation ranged treatments from 50 to $400 \mathrm{~L} / \mathrm{m}^{3}$ soil. They found that although plants were able to survive and grow at all treatments, shoot dry weight increased as water amount increased from 50 to $250 \mathrm{~L} / \mathrm{m}^{3}$ soil. Amoroso et al. (2011) potted Thuja plicata 'Martin' plants into $3 \mathrm{~L}$ containers. Two types of overleaf irrigation were scheduled (normal water amount and 33\% of normal water amount). They found that normal irrigation regime affected positively plant growth (shoot dry weight). Garas (2011) reported that applying the moderate irrigation level $(0.75 \mathrm{~L} / \mathrm{pot})$ and the highest one $(1 \mathrm{~L} / \mathrm{pot})$ increased fresh and dry weights of leaves of some Hibiscus rosa-sinensis cultivars. The highest dry weight of stem was obtained when the moderate irrigation level was applied.

On the other hand, deficit irrigation procured a negative influence on plant weight. Shimizu and YanWen (2007) stated that water stress significantly reduced the dry weights of each organ and the whole of Betula ermanii plant. 
D'souza and Devaraj (2011) found that drought stress reduced dry and fresh weight of Dolichos lablab (HA-4 cultivar).

On the contrary, when Scheiber et al. (2008) observed that irrigation quantity did not affect final dry weights of shoot and root of Solenostemon scutellarioides (coleus). However, Fascella et al. (2011) observed that two potted Euphorbia x lomi hybrids ('Nam Chok' and 'Udom Sab') plants with deficit irrigation showed higher top and root dry weight than control plants.

Referring to the effect of irrigation treatments on root length, some researchers observed that the more water was available to plant, the longer its roots will grow, and vice versa. Mortimer et al. (2003) exposed plants of Protea hybrida 'Sylvia' in glasshouse to watering regimes maintaining water at 20, 40 and $60 \%$ of field capacity in sand-filled pots. They revealed that higher water supply increased growth of the roots, reaching a maximum at $40 \%$ of field capacity. Padilla et al. (2009) found that roots of seven Mediterranean shrub species occurring in arid SE Spain, Anthyllis cytisoides, Atriplex halimus, Ephedra fragilis, Genista umbellata, Lycium intricatum, Retama sphaerocarpa, and Salsola oppositifolia responded to alterations in water supply by changing biomass allocation patterns by altering root length. D'souza and Devaraj (2011) found that drought stress reduced root length of Dolichos lablab (HA-4 cultivar).

On the contrary, more water affected root length negatively as mentioned by Chylinski et al. (2007) who found that in impatiens (Impatiens walleriana) and geranium (Pelargonium hortorum), roots were significantly longer in plants grown at $30 \%$ soil water content (SWC) as compared to those grown at $80 \%$ SWC. Fascella et al. (2011) observed that two potted Euphorbia x lomi hybrids ('Nam Chok' and 'Udom Sab') plants with deficit irrigation showed higher root length than control plants. Woods et al. (2011) observed that taproot length in seedlings of Larrea tridentata (a dominant shrub in North American hot deserts) correlated with root biomass and both too little and too much water stymied taproot extension.

However, Garas (2011) observed a beneficial effect on root length due to supplying plants of some Hibiscus rosa-sinensis cultivars with the moderate irrigation level $(0.75 \mathrm{~L} /$ pot $)$, compared to the highest and the lowest levels.

Moderate amounts of irrigation were preferred by some plants to encourage root growth. Mortimer et al. (2003) exposed Protea hybrida Sylvia (Protea susannae x Protea eximia) plants in glasshouse to watering regimes maintaining water at 20,40 and $60 \%$ of field capacity in sand-filled pots. They found that higher water supply resulted in increased growth of the roots in particular, reaching a maximum at $40 \%$ of field capacity. Garas (2011) stated that using the moderate irrigation level $(0.75 \mathrm{~L} /$ pot $)$ proved its mastery in increasing fresh and dry weights of roots of some Hibiscus rosa-sinensis cultivars. 
In regard of the effect of watering amount on content of carbohydrate, it was found that low levels of irrigation induced more carbohydrates. Nada et al. (1992) on Iris cv. "Ideal" and Nabih et al., (1992) on Freesia refrecta cv. Aurora noticed the positive effect of using the lowest irrigation level $(0.50 \mathrm{~L} / \mathrm{pot})$ on total carbohydrates content in stems and roots. Garas (2011) mentioned that stem content of total carbohydrates increased progressively by decreasing the irrigation level. The highest content in this regard was obtained by supplying plants with the lowest irrigation level $(0.50 \mathrm{~L} / \mathrm{pot})$.

However, some reports are in favor of moderate or high irrigation levels. ElShakhs et al. (2002) reported that increasing quantities of water improved the percentage of carbohydrates in the leaves of Dahlia pinnata. Shimizu and YanWen (2007) observed significant reductions of net photosynthesis of Betula ermanii plant under water deficiency treatments. El-Boraie et al. (2009) concluded that the highest value of poly saccharides content in roselle, Hibiscus sabdariffa was associated with 140 potential evapotranspiration (ETm), while the lowest value was associated with $60 \%$ ETm. The opposite was true for soluble sugar content.

In respect of the impact of irrigation regime on photosynthetic pigments, many authors observed the negative effect of water deficit on the content of chlorophyll and carotenoids. Chylinski et al. (2007) studied the response to water stress of impatiens and geranium. They found that the reduction in the $a+b$ chlorophyll concentration in leaves of impatiens was significantly stress dependent while no reaction in geranium was observed. D'souza and Devaraj (2011) found that drought stress reduced total chlorophyll of Hyacinth bean, Dolichos lablab (HA-4 cultivar). Caser et al. (2012) subjected rooted cuttings of Salvia dolomitica, S. sinaloensis and Helichrysum petiolare to five irrigation treatments (20-100\% of container water capacity). They mentioned that chlorophyll concentration decreased as water stress was intensified.

On the contrary, higher watering levels may decrease the concentration of photosynthetic pigments. Garas (2011) mentioned that leaf contents of chlorophyll (a) and (b) of some Hibiscus rosa-sinensis cultivars increased by decreasing irrigation level. The highest content was obtained due to giving plants the lowest irrigation level $(0.50 \mathrm{~L} / \mathrm{pot})$. On the other hand, different irrigation levels had insignificant effects on the content of carotenoids. However, Shimizu and YanWen (2007) stated that under water deficiency treatments on Betula ermanii plant, contents of chlorophyll $(\mathrm{a}+\mathrm{b})$ were not markedly changed.

The effect of irrigation amounts on plants might be interpreted by reports of several workers such as Eakes et al. (1991a, b) on Salvia splendens, Kiehl et al. (1992) on Chrysanthemum, Bastide et al. (1993) and Serpe \& Matthews (1994) on Begonia, El-Ashry et al. (1998) on Strelitizia reginae, Ali et al. (1998) on rose and Moftah and Al-Humaid (2004) on Polianthes tuberosa cv. Double. They concluded that holding soil water as a result of water soil stress caused a 
steady decrease in relative water content in the plants. Such decline in plant water potential would probably decrease all internal processes as net photosynthesis, cell division, enlargement and reduction of epidermal cell turgidity. Shaban et al. (2007) also noticed that the increase in amount of irrigation water led to increase in leaf water potential of 19 tree and shrub species.

ShuYong et al. (2007) showed that the net photosynthetic rate, transpiration rate, water use efficiency and light use efficiency of Euonymus fortunei var. radicans leaf has notable threshold value to the variation of soil moisture. With the increase of soil moisture, the number of light compensation point declines while light saturation point, the maximum net photosynthetic rate and apparent quantity yield are all increasing. ShuMing et al. (2008) found that diurnal courses of photosynthetic rate of six-year-old Eucommia ulmoides stump plants showed double peak in normal or little water supply condition and a single peak under greater amount of water supply, and the rate of photosynthesis increased.

\section{References}

Ali, M.A., El-Ashry, A.I. and Desouky, M.T. (1998) Water relations, growth and flowering of Eiffle Tower rose as influenced by soil moisture stress and paclobutrazol. Menofiya J. Agric. Res., 23 (5), 1345-1366.

Álvarez, S., Bañón, S., Jesús, M. and Blanco, S. (2013) Regulated deficit irrigation in different phenological stages of potted geranium plants: water consumption, water relations and ornamental quality. Acta Physiol. Plantarum, 35 (4), 1257-1267.

Amoroso, G., Frangi, P., Piatti, R. and Fini, A. (2011) Effect of mulching and irrigation on container-grown plant production. Acta Hort., 889, 573-579.

Armitage, A.M., Carlson, W.H. and Flore, J.A. (1981) The effect of temperature and quantum flux density on the morphology, physiology, and flowering of hybrid geraniums. J. Amer. Soc. Hort. Sci., 106, 643-647.

Bastide, B., Sipes, H. J.D. and Ting, J.P. (1993) Effect of sever water stress on aspects of crassulacean acid metabolism in xerosices. Plant Physiol., 103 (4), 1089-1096.

Björkman, O. (1980) Responses and adaptation of photosynthesis to high temperatures, In: Turner, C. and P. J. Kramer (Ed.). pp. 233-249. Adaptations of Plants to Water and High Temperature Stress. Wiley Interscience, New York.

Blanusa, T. and Cameron, R. (2009) Bedding plants in a changing climate. Plantsman, $8(4), 250-253$.

Caser, M., Ruffoni, B. and Scariot, V. (2012) Screening for drought tolerance in Salvia spp. and Helichrysum petiolare: a way to select low maintenance ornamental plants. Acta Hort., 953, 239-246.

Chylinski, W.K., Lukaszewska, A.J. and Kutnik, K. (2007) Drought response of two bedding plants. Acta Physiol. Plantarum, 29 (5), 399-406.

Egypt. J. Hort. Vol. 41, No.1 (2014) 
Collins, P.C. and Blessington, T.M. (1981) Influence of production and ancymidol on foliage plants. Hort. Sci., 16, 215-266.

Collins, P.C. and Blessington, T.M. (1982) Postharvest effects of various light sources and duration on keeping quality of Ficus benjamina L. Hort. Sci., 17, 908-909.

Conover, C.A. and Poole, R.T. (1977) Effects of cultural practice on acclimatization of Ficus benjamina L. J. Amer. Soc. Hort. Sci., 102, 529-531.

Correa-Tedesco, G., Rousseaux, M.C. and Searles, P.S. (2010) Plant growth and yield responses in olive (Olea europaea) to different irrigation levels in an arid region of Argentina. Agric. Water Manage., 97 (11), 1829-1837.

D'souza, M.R. and Devaraj, V.R. (2011) Specific and non-specific responses of Hyacinth bean (Dolichos lablab) to drought stress. Indian J. Biotech., 10 (1), 130-139.

Duncan, D.B. (1955) Multiple range and multiple F tests. Biometrics. Intl. Biometric Soc., 11 (1), 1-42.

Eakes, D.J., Wright, R.D. and Seiler, J.X. (1991 a) Water relations of Salvia splendens 'Bonfire' as influenced by potassium nutrition and moisture stress conditioning. $J$. Amer. Soc. Hort. Sci., 116 (4), 712-715.

Eakes, D.J., Wright, R.D. and Seiler, J.X. (1991 b) Moisture stress conditioning effects on Salvia splendens 'Bonfire'. J. Amer. Soc. Hort. Sci., 116 (4), 716-719.

El-Ashry, A.L., Dsouky, M.T. and Ali, M.A. (1998) Response of Strelitzia reginae Ait., to soil moisture levels and GA3 applications. Egypt. J. Appl. Sci., 13 (9), 132-145.

El-Boraie, F.M., Gaber, A.M. and Abdel-Rahman, G. (2009) Optimizing irrigation schedule to maximize water use efficiency of Hibiscus sabdariffa under Shalatien conditions. World J. Agric. Sci., 5 (4), 504-514.

El-Hanafy, S.H., Nabih, A. and Badawy, O.E.F. (2006) Effect of different irrigation periods and chemical fertilization on growth, flowering, bulb production and chemical constituents of on Ornithogalum thrysoides Jacq. Bull. Fac. Agric, Cairo Univ., 57, 745-774.

El-Shakhs, M.H., Auda, M.S. and Ahmed, A.K. (2002) Effect potassium sulphate and soil moisture on water use, growth and flowering of Dahlia pinnata Cav. J. Agric. Res. Tanta Univ., 281, 132-156.

Everett, T.H. (1981) The New York Botanical Garden Illustrated Encyclopedia of Hort. Garland Publishing, Inc. New York \& London. pp. 3075-3076.

Fascella, G., Maggiore, P., Cara, M.D. and Zizzo, G.V. (2011) Growth and flowering response of Euphorbia x Lomi poysean cultivars under two irrigation regimes. Acta Hort., 893, 939-943.

Faucon, Ph. (2005) website: http://www.desert-tropicals.com/ Plants/ Araliaceae/ Schefflera_ arboricola.html. 
Fox, L. and Montague, T. (2009) Influence of irrigation regime on growth of select field-grown tree species in a semi-arid climate. J. Environ. Hort., 27 (3), 134-138.

Garas, E.A.K. (2011) Effect of growing media, irrigation rates and grafting on growth and flowering of Hibiscus spp. plants. Ph. D. Thesis, Dept. Ornamental Hort., Fac. Agric., Cairo Univ., 276-283.

Hansen, C.W. and Petersen, K.K. (2004) Reduced nutrient and water availability to Hibiscus rosa-sinensis 'Cairo Red' as a method to regulate growth and improve postproduction quality. European J. Hort. Sci., 69 (4), 159-166.

Herbert, D., Philips, P.J. and Strange, R.E. (1971) Determination of total carbohydrates. Methods in Microbiology. Acad, Press, London and New York, 5B, 58, 209-344.

Iersel, M.W., Van, S. Dove, Jong-Goo, K. and Burnett, S.E. (2010) Growth and water use of petunia as affected by substrate water content and daily light integral. Hort Science, 45 (2), 277-282.

Wikipedia (2009) http://en.wikipedia.org/wiki/Schefflera_arboricola.

Irmak, S. and Rathje, W.R. (2008) Plant growth and yield as affected by wet soil conditions due to flooding or over-irrigation. University of Nebraska-Lincoln Extension, Institute of Agriculture and Natural Resources. Neb Guide, G1904.

Kafi, M., Asadi, H. and Ganjeali, A. (2010) Possible utilization of high-salinity waters and application of low amounts of water for production of the halophyte Kochia scoparia as alternative fodder in saline agroecosystems. Agric. Water Management, 97 (1), 139-147.

Kazaz, S., Ucar, Y., Askin, M.A., Aydinsakir, K., Senyigit, U. and Kadayifci, A. (2010) Effects of different irrigation regimes on yield and some quality parameters of carnation. Scientific Res. and Essays, 5 (19), 2921-2930.

Kiehl, P.A., Leith, J.H. and Burger, D.W. (1992) Growth response of Chrysanthemum to various container medium moisture tension levels. J. Amer. Soc. Hort. Sci., 117 (2), 224-229.

Kojian, R. (2009) Website: http://www.gardenology.org/wiki/Schefflera_arboricola.

Kubatsch, A., Grüneberg, H. and Ulrichs, C. (2005) Acclimatization of Ficus benjamina to the temperature and irradiance conditions in interior landscapes. J. Appl. Bot. Food Qual. 79, 117-121.

Kubatsch, A., Grüneberg, H. and Ulrichs, C. (2007) The effect of low light intensity and temperature on growth of Schefflera arboricola in interior landscapes. Hort. Science, 42 (1), 65-67.

Lance, C.J. and Guy, C.L. (1992) Chances in pigment levels, rubisco and respiratory enzyme-activity of Ficus benjamina during acclimation to low irradiance. Physiol. Plant, 86, 630-638.

Egypt. J. Hort. Vol. 41, No.1 (2014) 
Lucia, B.de (2009) Response of potted Australian ornamental plants to different soil water conditions. Acta Hort., 807 (1), 277-282.

Menne, A. (1992) Reaktion einiger zierpflanzen auf mehrtägige fluktuationen von temperatur und lichtintensität. University Hannover, Germany, Ph. D. Thesis.

Moftah, A.E. and Al-Humaid, A.L. (2004) Effect of kaolin and pinolene film forming polymers on water relation and photosynthetic rate of tuberose (Polianthes tuberosa L.) plants under water deficit condition. J. App. Hort. Lucknow, 6 (2), 15-22.

Mortensen, L.M. (1986) Effect of relative humidity on growth and flowering of some greenhouse plants. Scientia Horticulturae, 29 (4), 301-307.

Mortensen, L.M. and Gislerød, H.R. (1990) Effects of air humidity and supplementary lighting on foliage plants. Scientia Horticulturae, 44 (3-4), 301-308.

Mortimer, P., Swart, J.C., Valentine, A.J., Jacobs, G. and Cramer, M.D. (2003) Does irrigation influence the growth, yield and water use efficiency of the Protea hybrid 'Sylvia' (Protea susannae x Protea eximia). South African J. Botany, 69 (2), 135-143.

Nabih, A., Aly, A.A. and Nada, M.K. (1992) Growth, floweing and corm productivity of Freesia refracta cv. Aurora as affected by different irrigation periods and chemical fertilization. Egypt. J. Appl. Sci., 7 (6), 265-283.

Nada, M.K., Nabih, A. and Aly, A.A. (1992) Effect of irrigation periods and chemical fertilization on growth, flowering and bulbs productivity of Iris bulbs cv. Ideal. Egypt. J. Appl. Sci., 7 (6), 306-324.

Padilla, F.M., Miranda, J.D., Jorquera, M.J. and Pugnaire, F.I. (2009) Variability in amount and frequency of water supply affects roots but not growth of arid shrubs. Plant Ecology, 204 (2), 261-270.

Parnell, J.R. (1989) Ornamental plant growth responses to different application rates of reclaimed water. Proc. The Florida State Horti. Soc. Publ., 1990, 102, 89-92.

Reyes, T., Nell, T.A., Barrett, J.E. and Conover, C.A. (1996) Irradiance level and fertilizer rate affect acclimatization of Chamaedorea elegans Mart, Hort. Sci., 31, 839-842.

Salvador, R., Bautista-Capetillo, C. and Playan, E. (2011) Irrigation performance in private urban landscapes: a study case in Zaragoza (Spain). Landscape and Urban Planning, 100 (3), 302-311.

Saric, M., Kastrori, R., Curie, R., Cupina, T. and Gerie, I. (1976) Chlorophyll determination. Univ. U. Noven Sadu Praktikum is Kiziologize Bilijaka, Beogard, Hauncna, Anjiga, 215 p.

Sawwan, J.S. and Ghunem, R.S. (1999) Light acclimatization of Schefflera arboricola, Adv. Hort. Sci., 13,151-155.

Scheiber, S.M., Beeson, Jr. R.C., Chen, J., Wang, Q. and Pearson, B. (2008) Evaluation of irrigation frequency and quantity on leaf gas exchange, growth and nitrate leaching of Coleus in a simulated landscape. Hortscience, 43 (3), 881-884.

Egypt. J. Hort. Vol. 41, No.1 (2014) 
Serpe, M.D. and Matthews, M.A. (1994) Changes in cell wall yielding and growth in Begonia argenteo-growttata leaves during the development of water deficits. Plant and Cell Physiol., 132 (4), 619-626.

Shaban, M., Khajeddin, S.J. and Karimzade, H.R. (2007) Effect of water stress on leaf water potential of some trees and shrubs. Iranian J. Rangelands and Forests Plant Breeding and Genetic Res., 15 (1), 51-62.

Shen, G.W. and Seeley, J.G. (1983) The effect of shading and nutrient supply on variegation and nutrient content of variegated cultivars of Peperomia obtusifolia. J. Amer. Soc. Hort. Sci., 108, 429-433.

Shimizu, H. and YanWen, F. (2007) Ozone and/or water stresses could have influenced the Betula ermanii Cham. forest decline observed at Oku-Nikko, Japan. Environ. Monitoring and Assessment, 128 (1/3), 109-119.

ShuMing, L., ZongSuo, L. and JuanE, D. (2008) Photosynthetic characteristics and growth of sprout of Eucommia ulmoides under different water conditions. $J$. Northwest A \& F Univ., Natural Science Edition, 36, 4, 89-93.

ShuYong, Z., ZeFu, Z., JiangBao, X. and GuangCan, Z. (2007) The responses of Euonymus fortunei var. radicans Sieb. leaf photosynthesis to light in different soil moisture. Acta Botanica Boreali-Occidentalia Sinica, 27 (12), 2514-2521.

Singh, G. (2011) Evaluation of irrigation practices for growth, biomass production, and nutrient partitioning in Eucalyptus camaldulensis plants in Indian dry zone. $J$. Sustainable Forestry, 30 (6), 564-583.

Snedecor, C.W. and Cochran, W.G. (1989) Two-way classification, Analysis of Variance Statistical Methods $8^{\text {th }}$ ed., Iowa State Univ. Press Ames, Iowa, U.S.A. p. 254-268.

Stabler, L.B. and Martin, C.A. (2004) Irrigation and pruning affect growth water use efficiency of two desert-adapted shrubs. Acta Hort., 638, 255-258.

Starr, F. and Starr, K. (2009) Website: http://www.hear.org/ starr/plants/ images/ species/?q= schefflera+arboricola.

Valdez-Aguilar, L.A., Grieve, C.M., Poss, J. and Layfield, D.A. (2009) Salinity and alkaline $\mathrm{pH}$ in irrigation water affect marigold plants: II. Mineral ion relations. HortScience, 44 (6),1726-1735.

Warsaw, A.L., Fernandez, R.T., Cregg, B.M. and Andresen (2009) Container-grown ornamental plant growth and water runoff nutrient content and volume under four irrigation treatments. HortScience, 44 (6), 1573-1580.

Woods, S.R., Archer, S.R. and Schwinning, S. (2011) Early taproot development of a xeric shrub (Larrea tridentata) is optimized within a narrow range of soil moisture. Plant Ecology, 212 (3), 507-517.

Egypt. J. Hort. Vol. 41, No.1 (2014) 
Zhenzhe, W. and Changze, L. (2009) Flora of Taiwan. Huayu Nature Book Trade Co. Ltd. 3:1002.Website: http://tai2.ntu.edu.tw/ udth/bin/fot1.exe/search? $\mathrm{kw}=$ Schefflera+arboricola \& B1=+BEGIN+\&RID $=0$.

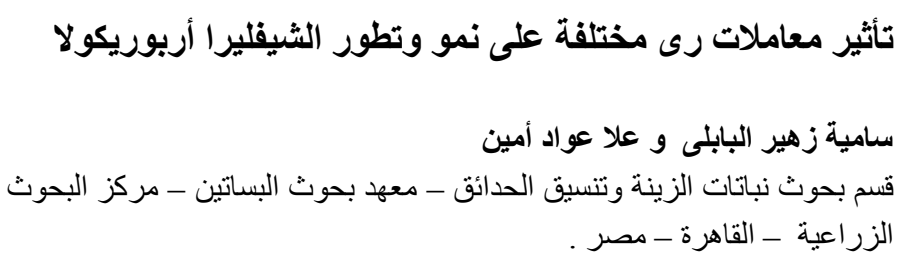

أجريت هذه الدر اسة فى قسم بحوث نباتات الزينة ، معهد بحوث البساتين مركز البحوث

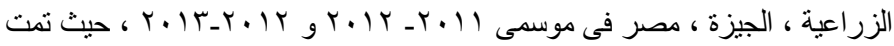

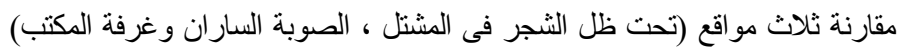

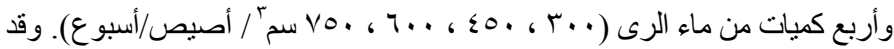

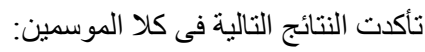

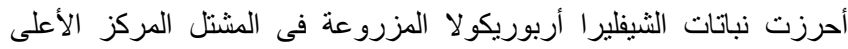

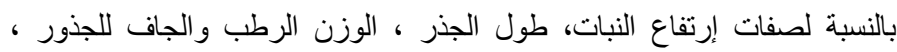

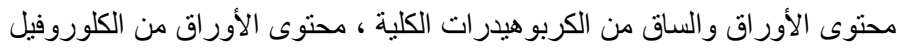

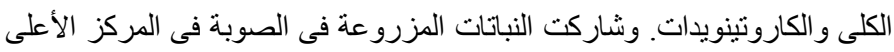

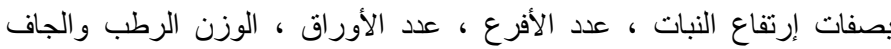

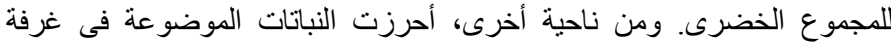
المكتب بغرض التزيين أقل القيم لجميع الصفات التى جرت الته در استها.

كان للنباتات التى رويت بمقدار . ..r سمّ ماء/أصيص/أسبوع أعلى القيم

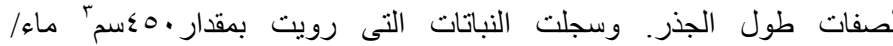

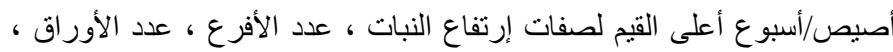

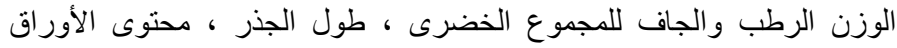

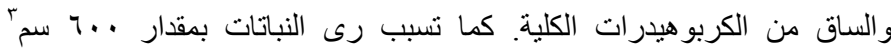

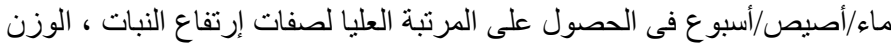

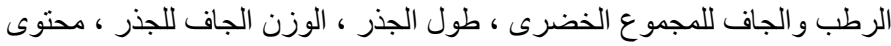

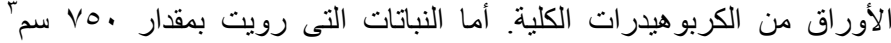
ماء/أصيص/أسبوع فلم تحقق سوى المرتبة الدنيا لجميع الصفات المدروسة. 


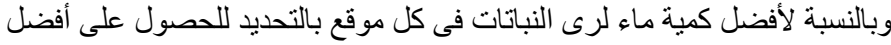

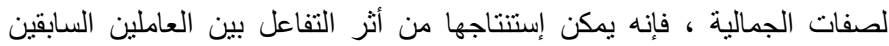

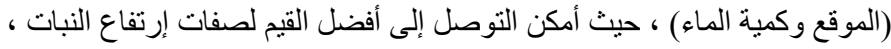

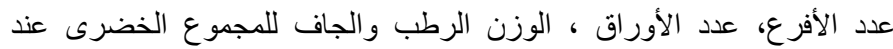

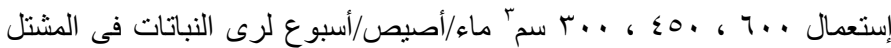

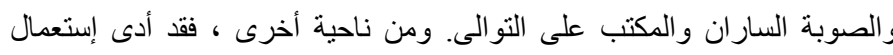
.

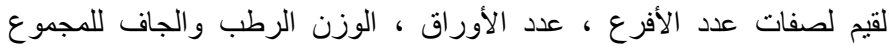

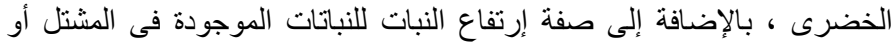

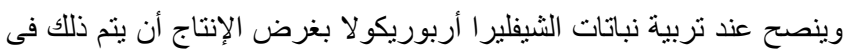

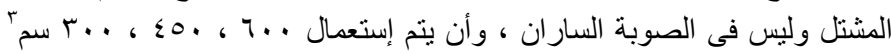

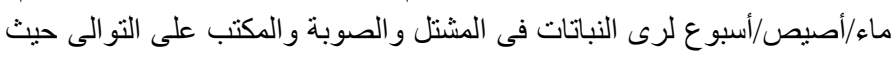

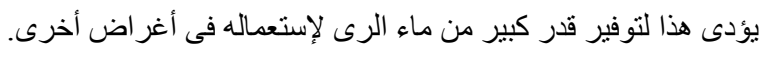

